Article

\title{
Production, Properties and Performance of Slag-Based, Geopolymer Foams
}

\author{
Georgia-Maria Tsaousi * (D) and Dimitrios Panias
}

check for updates

Citation: Tsaousi, G.-M.; Panias, D.

Production, Properties and

Performance of Slag-Based,

Geopolymer Foams. Minerals 2021, 11,

732. https://doi.org/10.3390/

$\min 11070732$

Academic Editors: Luis Pérez Villarejo and George Angelopoulos

Received: 10 June 2021

Accepted: 1 July 2021

Published: 6 July 2021

Publisher's Note: MDPI stays neutral with regard to jurisdictional claims in published maps and institutional affiliations.

Copyright: (c) 2021 by the authors. Licensee MDPI, Basel, Switzerland. This article is an open access article distributed under the terms and conditions of the Creative Commons Attribution (CC BY) license (https:// creativecommons.org/licenses/by/ $4.0 /)$.
Laboratory of Metallurgy, School of Mining and Metallurgical Engineering, National Technical University of Athens, 11527 Athens, Greece; panias@metal.ntua.gr

* Correspondence: margitsaousi@metal.ntua.gr; Tel.: +30-21099772299

\begin{abstract}
This paper demonstrates the transformation of the industrial residue (copper slag) of a Swedish mining and smelting company "Boliden", through geopolymerization, into advanced building materials. The main objective of this experimental study is the assessment of the appropriate conditions for the preparation of alkali-activated slag-based geopolymer pastes with further foaming production, by aluminum powder addition. The alkaline-activating solution used was $\mathrm{KOH}$, at a constant concentration $(8 \mathrm{M})$. The effect of crucial operating parameters, such as S/L ratio $(3.5-4.5 \mathrm{~g} / \mathrm{mL})$ and aluminum powder addition $(0.12 \%-0.22 \%)$, on the geopolymer paste were studied, in order to achieve the optimum rheological conditions of the slurry. The physical properties of the materials were examined after the appropriate curing process $\left(24 \mathrm{~h}\right.$ at $\left.70{ }^{\circ} \mathrm{C}\right)$, with density values ranging between 805 and $1100 \mathrm{~kg} / \mathrm{m}^{3}$. The mechanical performance of the materials ranged between 1.28 and $2 \mathrm{MPa}$ (compressive strength), and from 0.25 to $0.85 \mathrm{MPa}$ (flexural strength), indicating the strong correlation of physical and mechanical properties. To assess the porosity and the size distribution of the voids, image processing techniques were applied on digital images of selected samples. According to these results, the synthesized materials exhibit similar, or even better, properties than the current concrete porous materials.
\end{abstract}

Keywords: geopolymerization; slag; foaming; porosity

\section{Introduction}

Extractive and raw materials processing industries are strongly related to the generation of large volumes of solid wastes and residues. In 2016, mining and quarrying activities in the EU-28 were accountable for 25 billion tones, almost $25 \%$ of the total waste generated [1] (Figure 1), and these steadily increased in the following years.

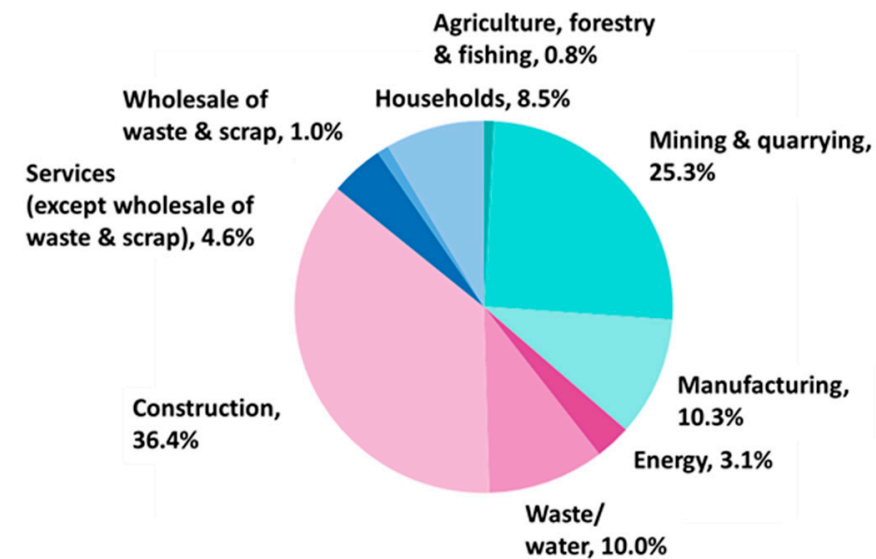

Figure 1. Waste generation by economic activities and households, EU-28, 2016. 
Among the different industrial residues of the extractive industry, those derived from metallurgical activities, i.e., slags, sludges, drosses, etc., stand out, as they represent major streams in Europe, with potential utilization paths as secondary resources in several industrial sectors, mainly the ones of constructions and building materials, in particular.

Within decades of industrial activities, a huge amount of stored industrial waste in landfills and untapped side streams has accumulated in Europe, constituting an enormous wealth that waits to be unlocked and valorized. As envisioned in the EU 2020 agenda [2], the EU boosts the transition to a resource-efficient and -sustainable society. Several European initiatives have been developed to tackle this challenge, through increasing the resource efficiency of current processes and products and re-thinking the current linear economic model towards a circular approach. In this vision, products, processes, and solutions are geared towards the closure of highly interconnected material cycles. The above-mentioned issues and needs of the raw materials (RM) sector can be addressed by the valorization of industrial residue side streams, opening new horizons for RM extraction and processing industries, in terms of the minimization of landfilling and the valorization of residues to added-value products that can be absorbed in high-volume markets.

A variety of industrial solid residues or wastes, such as fly ashes, metallurgical slags, and mine wastes, as well as industrial minerals such as kaolinite, feldspars and perlite [3-7], have been used for the synthesis of geopolymers. Extended research activities in the field of geopolymer synthesis over the last decade has proved that geopolymers possess excellent mechanical and physicochemical properties, resulting in high compressive strength values, even for materials with a low density range. The latter comes out through the combination of the geopolymerization process with a foaming technique, indicating that geopolymer foam boards are considered ideal alternatives for many industrial applications, mainly in the construction sector.

Geopolymerization is based on an exothermic heterogeneous chemical reaction between a solid aluminosilicate raw material and an alkali metal silicate solution, under atmospheric conditions and temperatures up to $100{ }^{\circ} \mathrm{C}$. The materials synthesized by this reaction mainly present an amorphous or semi-crystalline $\mathrm{Si}-\mathrm{O}-\mathrm{Al}$ and /or $\mathrm{Si}-\mathrm{O}-\mathrm{Si}$ frame [8-12].

The foaming process ideally aims at forming a large number of small, individual voids (closed cells), or interconnected networks of voids (open cells) inside a viscous material (i.e., a paste or a polymer). The control of the nature, size and distribution of voids is the most critical step in the production of foamy materials, specifying their final density and strength [13]. Voids can be produced by the following two methods: (1) by introducing a large volume fraction of air bubbles [14], usually through the addition of surfactants; (2) by endogenous gas generation, which can be achieved by mixing gas-releasing agents, such as aluminum powder or hydrogen peroxide, in a cement-like paste or a mortar. Hydrogen peroxide $\left(\mathrm{H}_{2} \mathrm{O}_{2}\right)$ is a widely known inorganic foaming agent that is thermodynamically unstable, and therefore can be easily decomposed to water and oxygen gas (Equation (1)), with the latter playing the role of the blowing agent [15].

$$
2 \mathrm{H}_{2} \mathrm{O}_{2} \rightarrow 2 \mathrm{H}_{2} \mathrm{O}+\mathrm{O}_{2}
$$

The synthesis of low-density geopolymers using hydrogen peroxide is influenced by the optimization of the kinetics of peroxide decomposition, with the production of oxygen and the increase in viscosity of the geopolymer paste [16].

Alumina powder is also a very well-known foaming agent, which reacts with water and hydroxide in an alkaline environment, liberating bubbles of hydrogen gas and forming hydrolyzed metal complexes. This takes place according to a reaction similar to the equation (Equation (2)) below [17]:

$$
\mathrm{Al}(\mathrm{s})+3 \mathrm{H}_{2} \mathrm{O}(\mathrm{l})+\mathrm{OH}^{-}(\mathrm{aq}) \rightarrow \mathrm{Al}(\mathrm{OH})_{4}^{-}(\mathrm{aq})+1.5 \mathrm{H}_{2}(\mathrm{~g})
$$


The release of the aforementioned gases contributes to the formation of pores prior to the hardening of the geopolymer pastes, leading to materials with a high overall porosity and low density values after the appropriate curing process. The final hardened structures present good mechanical and thermal properties and can therefore be used for applications in acoustic panels and in lightweight pre-fabricated components for thermal insulation purposes. Nevertheless, hydrogen peroxide has been proved as the foaming agent that, under specific conditions, results in materials with lower thermal conductivity values [16].

The paper proposes a valorization approach of the copper slag from the Swedish mining and smelting company Boliden, which leads to the production of high added-value foamy materials for the construction sector. During this study, different parameters were studied for the development of slag-based geopolymer foams. The produced materials presented similar, or even better, physical properties compared to conventional ones $[18,19]$. In summary, the produced material of this study is beneficial for the extractive industry, while it offers a superior and cheaper solution for insulating and/or precast purposes in the construction sector, competing with materials such as foam concrete and AAC [18-24].

\section{Materials and Methods}

\subsection{Materials}

The raw materials used for the synthesis of foam boards consist of copper slag (byproduct of copper production operations at the Rönnskär smelter), aqueous potassium hydroxide solution, prepared by dissolving potassium hydroxide pellets (Merck Chemicals, $99 \%$ purity) in deionized water and aluminum powder, which was selected as foaming agent (-325 mesh, 99.5\%).

The copper slag primarily contains silica $\left(\mathrm{SiO}_{2}\right)$ and iron (II) oxide, which have been combined to form a chemically stable, glass-like compound. The iron comes from the copper parent mineral and the silica is brought in the form of sand used to form the slag during the smelter's processes. The received raw material after $24 \mathrm{~h}$ drying at $100{ }^{\circ} \mathrm{C}$, was finely grinded and sieved ( $\leq 60 \mu \mathrm{m}$ particle size) to be proper for characterization and further utilization in geopolymerization process.

\subsection{Paste Preparation and Foaming}

The received copper slag was used as silicious raw material, constituting, with the appropriate activator, the geopolymer precursor for further foaming, through the addition of a blowing agent to produce porous materials.

The synthesis of the paste was performed by mixing the solids with the alkaline solution (KOH solution) until a homogenous slurry was obtained. The selected $\mathrm{KOH}$ concentration was equal to $8 \mathrm{M}$ according to published studies, reporting that at lower alkalinity level, the $\mathrm{OH}^{-}$ion amount is inadequate to facilitate the dissolution of silicate and aluminate species that promote polymerization [25]. On the other hand, under higher alkaline conditions the oligomeric silicate species lose their stability in favor of mononuclear silicate species at extremely high alkaline conditions $[3,8,26]$.

This means that the species in equilibrium at extremely high alkaline conditions shift towards mononuclear species formation, minimizing the concentration of oligomeric silicate species in the aqueous phase and thus, decelerating the process of polycondensation and the effectiveness of the geopolymeric process.

The rheological properties investigation of slag-based geopolymer pastes was performed. The effect of solid-to-liquid ratio (S/L: 3-4.5 g/mL), in the setting time and viscosity of the slurries, was studied. Immediately after the preparation of geopolymer paste, based on the selected solid/liquid ratio (S/L: $3.5 \mathrm{~g} / \mathrm{mL})$, the effect of different $\mathrm{Al}$ powder $(0.12 \%-0.22 \%)$ contents in the geopolymer paste on the foaming capacity of the fresh slurry was studied. Thus, appropriate amount of $\mathrm{Al}$ powder was added in the mixture under rapid stirring (10 s) and the foamed paste poured into molds $\left(50 \times 50 \times 50 \mathrm{~mm}^{3}\right)$ and exposed to a temperature of $70{ }^{\circ} \mathrm{C}$ for a period of $48 \mathrm{~h}$. The maximum linear shrinkage observed in the final materials was $1 \%$. After the heating process, the elements were dis- 
mantled and stored under laboratory conditions for a period of 28 days in order to obtain full strength for further evaluation of their physical, mechanical and thermal properties.

\subsection{Characterization Methods}

\subsubsection{Analytical Methods}

Raw materials (slag) characterization: Chemical analysis of the sample was carried out as follows: (a) Using the energy dispersive X-ray fluorescence (EDXRF) instrument Xepos (SPECTRO A.I. GmbH company); (b) using fusion method, where the sample is dissolved in the molten flux $\left(\mathrm{Li}_{2} \mathrm{~B}_{4} \mathrm{O}_{7}\right.$ and $\left.\mathrm{KNO}_{3}\right)$ at temperature of around $1050{ }^{\circ} \mathrm{C}$. The final melt is totally dissolved in nitric acid and the metals content is performed by AAS (atomic adsorption spectroscopy). These two methods are the most suitable for the chemical analyses of slag samples, according to the literature [27-30]. However, the combination of both XRF and fusion methods was selected in this study for higher accuracy in the evaluation of specific elements. Crystallographic analysis made by P-XRD analysis of the sample was carried out by X-ray diffractometry, using a SIEMENS D5000 diffractometer with $\mathrm{Cu} \mathrm{K} \alpha 1$ (Ni-filtered) radiation, in the 2theta range from 2 to $60^{\circ}$ and $0.02^{\circ} / \mathrm{s} \mathrm{step.} \mathrm{The}$ microstructure of the material was examined using a scanning electron microscope (JEOL JSM $6380 \mathrm{LV}$ ). Specific gravity was measured using a glass pycnometer according to ASTM standard method C128.

Geopolymer pastes characterization: The resulting geopolymer pastes were evaluated for their rheological properties. The setting time of the geopolymer pastes was measured using a MATEST Vicat apparatus in accordance with EN 196-3:2005. The viscosity of the geopolymer pastes was measured immediately after their preparation at ambient temperature, using a Brookfield viscometer $\mathrm{LV}+$.

Geopolymer foams characterization: The resulting geopolymer foams were evaluated for their thermophysical properties. The apparent density " $d$ " of the foam boards was calculated using the equation $\mathrm{d}=\mathrm{m} / \mathrm{V}$, where $\mathrm{m}=$ weight of the board, and $\mathrm{V}=$ volume of the board. In order to achieve smooth and uniform dimensions that are appropriate for further evaluation, the measurement took place after cutting the final materials using a band saw. The water absorption test of the specimens was determined in accordance with CEN 13755 standard [31]. The samples, after being dried to constant mass in the early step, were placed in a container of deionized water (to remove dissolve gases) at a room temperature of $\sim 22^{\circ} \mathrm{C}$ with a level reaching half the height. Water was gradually added after $1 \mathrm{~h}$ to $3 / 4$ of the height, after $2 \mathrm{~h}$ to complete immersion to a depth of $25 \pm 5 \mathrm{~mm}$. The samples were removed from the water after $48 \mathrm{~h}$, wiped with a damp cloth, and weighed quickly. The test was measured for five samples and an average value of measurements was taken. The total water absorption is calculated as per Equation (3), as follows:

$$
\mathrm{A}=\left(\mathrm{m}_{\mathrm{w}}-\mathrm{m}_{\mathrm{d}}\right) /\left(\mathrm{m}_{\mathrm{d}}\right) \times 100 \%
$$

where $\mathrm{A}$ is total water absorption (\%), $\mathrm{m}_{\mathrm{d}}$ is mass of oven-dried sample in grams, $\mathrm{m}_{\mathrm{w}}$ is mass of the sample saturated with water in gram. The thermal conductivity measurement performed using HFM 446 Lambda Series-heat flow meter for testing insulation materials, Netzsch in the LabMet. Compressive and flexural strength measurements of the geopolymer foams were also performed on specimens using a servo-hydraulic loading machine (ASTM C109). For compressive strength measurement, three cubic specimens of $50 \mathrm{~mm}$ edge were used for each material and the mean value of the three measurements was reported as the compressive strength of the material. Flexural strength was calculated from a three-point bending test on the samples of size $40 \times 40 \times 160 \mathrm{~mm}^{3}$. The microstructure study of the porous materials was performed using a scanning electron microscope-JEOL6380LV.

\subsubsection{Image Processing Methods}

Image analysis was applied in geopolymer foams to evaluate the porosity of the samples. In this study, image analysis was carried out using the Image ${ }^{\circledR}$ software (V1.8.0). 
The digital images were acquired from the saw-cut flat surfaces of the geopolymer boards, using a commercial scanner at high resolution. The images were converted into grayscale 8-bit files, and the threshold adjustment took place. In any image, the dark-colored areas account for the pores of the sample while the bright ones indicate the geopolymer matrix. Through threshold adjustment, the area of dark objects was computed in pixels, and the porosity was calculated based on the area of the pores and the total area of the image.

\section{Results and Discussion}

\subsection{Characterization of Raw Material (Cu-Slag)}

Table 1 presents the chemical analysis of the sample, as well as the specific gravity measurement. The chemical analysis of copper slag (Boliden) shows that the material is rich in iron and silicon oxides. Amounts of aluminum and calcium are also detected, while small quantities of copper $(0.85 \%)$ and zinc $(2.14 \%)$ are present as well. These results are in accordance with the typical chemical analysis of copper slag samples, according to the literature [32-34]. As far as the specific gravity is concerned, the results show that copper slag is a heavy raw material with a value of $3.37 \mathrm{~g} / \mathrm{cm}^{3}$, which is the average true value of similar materials.

Table 1. Chemical analysis of copper slag.

\begin{tabular}{|c|c|c|c|c|c|c|c|c|c|c|}
\hline \multicolumn{11}{|c|}{ Oxides, \% w/w } \\
\hline $\mathrm{FeO}$ & $\mathrm{Al}_{2} \mathrm{O}_{3}$ & $\mathrm{SiO}_{2}$ & $\mathrm{Na}_{2} \mathrm{O}$ & $\mathrm{CaO}$ & $\mathrm{ZnO}$ & $\mathrm{MgO}$ & $\mathrm{CuO}$ & Others & Total, \% & S.G, $\mathrm{g} / \mathrm{cm}^{3}$ \\
\hline 44.41 & 3.30 & 39.95 & 1.05 & 4.08 & 2.14 & 1.77 & 0.85 & 2.08 & 99.61 & 3.37 \\
\hline
\end{tabular}

Crystallographic analysis, made by P-XRD analysis of raw material, was also performed, and the results are presented in Figure 2.

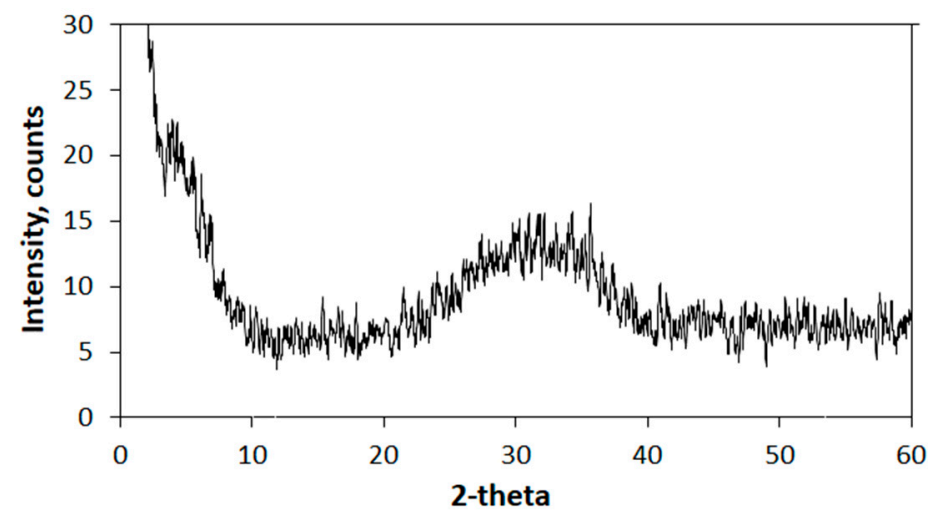

Figure 2. XRD pattern of copper slag.

In the XRD pattern of copper slag, there seems to be a broad hump in the region between $2 \theta=20$ and $40^{\circ}$, indicating the existence of amorphous silicate phases [33]. No evidence of any crystalline phase in this sample is shown, so this suggests that the slag is almost totally amorphous. Crystalline phases are well known for reducing the effectiveness of the slag under alkali-activation [34], due to the stability of these crystalline structures and their inability to dissolve in alkaline solutions [35], rendering copper slag as a proper raw material for geopolymerization processes. Microstructure study of the raw material was also performed. The results are presented in Figure 3. 


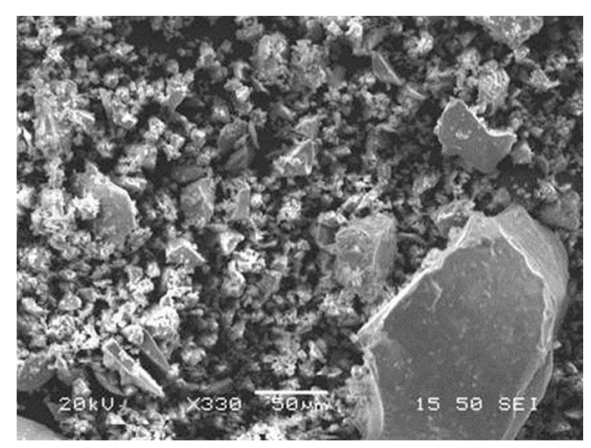

Figure 3. Microstructure images of copper slag at $330 \times$ magnification and $50 \mu \mathrm{m}$ scale.

SEM images confirm the amorphicity of the material, which was also indicated by the crystallographic analysis in Figure 2.

\subsection{Properties of Geopolymer Pastes and Foams}

\subsubsection{Effect of S/L on Rheological Properties of Geopolymer Pastes}

The aim of this study is to define the optimum rheological properties of the geopolymer pastes, which will be mixed up with $\mathrm{Al}$ powder (blowing agent) in the next step, to produce porous materials. This means that the rheology of the paste is a crucial factor controlling the quantity of gas (produced by $\mathrm{Al}$ powder) that will be entrapped in the geopolymer matrix, leading to successful foaming of the prepared slurry. As a result, setting-time tests and viscosity measurements (Figure 4), carried out on geopolymer pastes of different solidto-liquid ratios, enabling the appropriate rheological conditions to be defined. The effect of the solid-to-liquid (S/L) ratio on the geopolymer pastes setting time was investigated in the range of 3 to $4.5 \mathrm{~g} / \mathrm{mL}$. Lower S/L values resulted in watery pastes, with no potential to keep an adequate gas amount during foaming. Higher S/L values led to slurries with extremely high viscosities, as indicated by the intensive mixing conditions required during the mechanical stirring of the paste. Extremely high viscous pastes are not desirable for blowing agent addition, prohibiting the smooth gas release inside the matrix and resulting in non-homogeneous porous materials. The $\mathrm{KOH}$ concentration in the activating phase, and the curing temperature, were both kept constant at $8 \mathrm{M}$ and $70{ }^{\circ} \mathrm{C}$, respectively. The results are shown in Figure $4 \mathrm{a}$, where the setting time is plotted at different $\mathrm{S} / \mathrm{L}$ ratios.

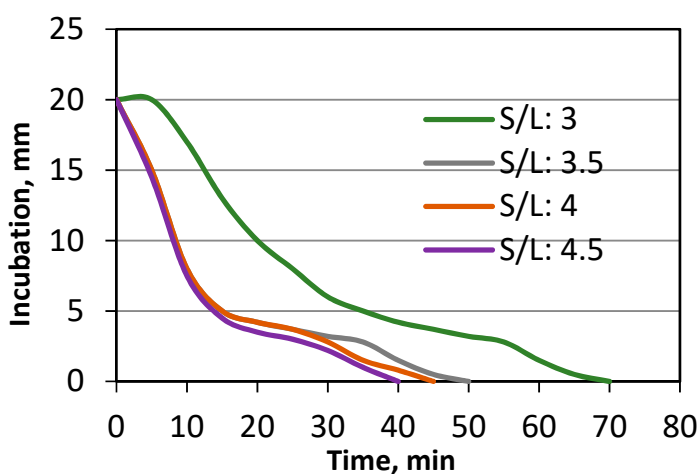

(a)

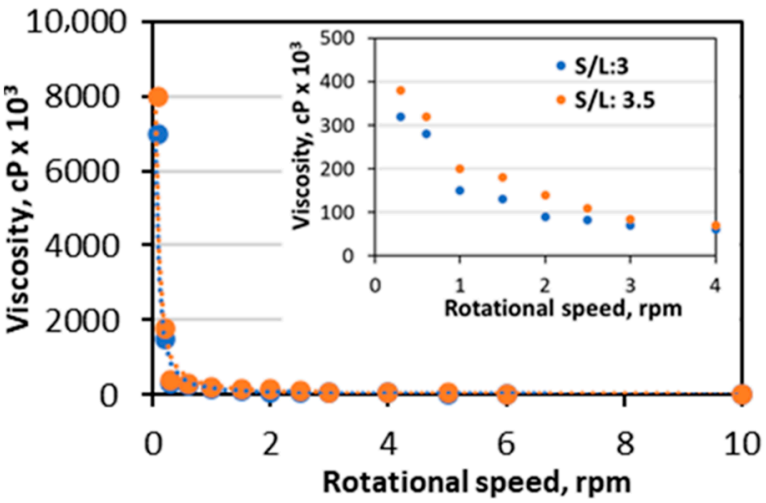

(b)

Figure 4. Effect of S/L ratio on the (a) setting time and (b) viscosity of geopolymer pastes with [KOH]: 8M. and curing temperature $70^{\circ} \mathrm{C}$.

The results presented in Figure 4a reveal the fast solidification of geopolymer pastes, ranging between 40 and $70 \mathrm{~min}$ in all of the cases. As a general trend, an increase in the $\mathrm{S} / \mathrm{L}$ ratio leads to faster paste solidification under constant conditions. This is attributed to the 
fact that an increased S/L ratio, which means there is a higher ratio of slag per volume of the activating solution, can cause an increase in the concentration of silicon and aluminum species in the aqueous phase of geopolymerization, accelerating the polycondensation phenomena, and therefore reducing the setting time of the pastes [36-38]. More specifically, the lowest studied $\mathrm{S} / \mathrm{L}$ value $(3 \mathrm{~g} / \mathrm{mL})$ prolongs the setting time to $70 \mathrm{~min}$, while the higher studied S/L ratios $(3.5-4.5 \mathrm{~g} / \mathrm{mL})$ follow the same, more or less, setting behavior, differentiating only at the final setting time, which varies between 40 and $50 \mathrm{~min}$ for all of the pastes.

However, each geopolymer system (depending on the raw material and the activating phase) presents a limited optimum S/L range, which is a blend of several parameters, constituted not only by the experimental results and measurements, but also by the empirical handling and evaluation of the materials. Thus, even though the pastes of the maximum S/L ratios resulted in accelerated hardening, at the same time they presented limited workability during the mixing stage, indicating difficulties for further treatment either in viscosity measurements (spindle could not be rotated inside the paste) or in the foaming process.

Ensuring proper viscosity in the base mix is vital in achieving optimum foaming. Therefore, it is necessary to explore the effect of the mass ratio of the solid-to-aqueous phase on the properties and pore structure of foamed geopolymers. According to the setting time results, pastes with S/L: 3 and $3.5 \mathrm{~g} / \mathrm{mL}$ proved to be appropriate for further rheological study, while a higher S/L level (4-4.5 mL) led to extra-thick slurries with no potential to be adjusted in the viscosity equipment, as the inserted spindle could not be rotated inside the samples. The results are shown in Figure $4 b$, where the viscosity of the paste is plotted at different rotational speeds.

Geopolymer pastes are non-Newtonian shear-thinning fluids that achieve very low viscosities at high shear stresses [39]. High viscosity values are achieved from low rotational speeds in both of the cases (S/L: 3 and S/L: $3.5 \mathrm{~g} / \mathrm{mL}$ ), but the slightly higher viscosity value $\left(8000 \mathrm{cP} \times 10^{3}\right)$ for the maximum $\mathrm{S} / \mathrm{L}$ ratio $(3.5 \mathrm{~g} / \mathrm{mL})$ confirms the setting time results (Figure $4 \mathrm{a}$ ), justifying the faster polymerization, and therefore solidification, of the pastes, due to the optimized polycondensation phenomena under the highest solid-toliquid ratio. Under low viscosity conditions, the generated gas bubbles can easily migrate, leading to a rapid collapse of the fresh foam paste [40]. According to these results, an S/L ratio $(3.5 \mathrm{~g} / \mathrm{mL})$ will be applied for further foaming of the paste, as this is more suitable for a stable foam structure in terms of regularity, porosity and pore distribution. Thus, the optimum produced geopolymer slurry (Table 2) was casted and cured in order to create a compact geopolymer material (Geo) for further evaluation before the foaming process application.

Table 2. Experimental conditions of compact geopolymer material (Geo).

\begin{tabular}{cc}
\hline $\mathrm{S} / \mathrm{L}, \mathrm{g} / \mathrm{mL}$ & 3.5 \\
{$[\mathrm{KOH}], \mathrm{M}$} & 8 \\
Curing time, $\mathrm{h}$ & 24 \\
Curing temperature, ${ }^{\circ} \mathrm{C}$ & 70 \\
\hline
\end{tabular}

The final material evaluated in terms of its physical and mechanical properties, and the results are collected in Table 3.

Table 3. Evaluation of optimum produced geopolymer material with S/L ratio $(3.5 \mathrm{~g} / \mathrm{mL})$ and $[\mathrm{KOH}]: 8 \mathrm{M}$.

\begin{tabular}{cccc}
\hline Material & Density, $\mathbf{k g} / \mathbf{m}^{\mathbf{3}}$ & Compressive Strength (after 28 Days), MPa & Flexural Strength (after 28 Days), MPa \\
\hline Geo & 2195 & 9 & 3.2 \\
\hline
\end{tabular}

According to the results, geo is a promising material for further foaming treatment, presenting good mechanical performance for the measured density level. Al powder 
addition in the slurry is expected to produce porous materials with homogenous porosity, decreased density, and satisfying strength values.

\subsubsection{Effect of Al Powder Addition on Geopolymer Foam Properties}

The effect of $\mathrm{Al}$ powder addition on the physical and mechanical properties of produced geopolymer foams (based on the optimum paste's recipe, defined by Figure 4) was studied under specific experimental conditions (Table 4).

Table 4. Experimental conditions of geopolymer foams with different $\% \mathrm{Al}$ powder addition.

\begin{tabular}{cc}
$\mathrm{S} / \mathrm{L}, \mathrm{g} / \mathrm{mL}$ & 3.5 \\
{$[\mathrm{KOH}], \mathrm{M}$} & 8 \\
$\mathrm{Al}$ powder, wt. $\%$ (to paste) & $0.12,0.15,0.18,0.22$ \\
Curing time, $\mathrm{h}$ & 24 \\
Curing temperature, ${ }^{\circ} \mathrm{C}$ & 70 \\
\hline
\end{tabular}

Figure 5 depicts the apparent density, and (a) compressive strength and (b) flexural strength of the foam boards as a function of the content of the foaming agent (Al powder) in the paste.

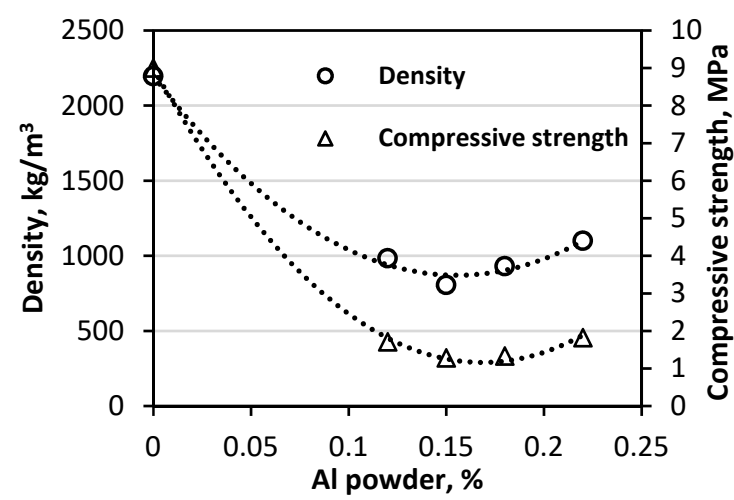

(a)

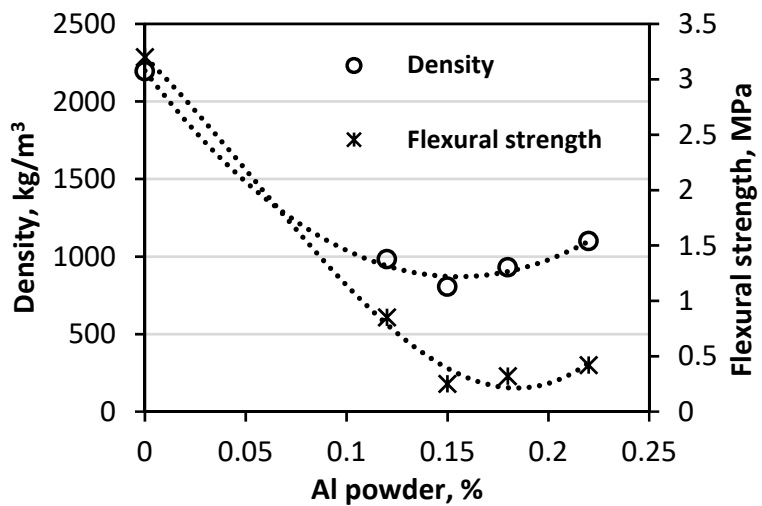

(b)

Figure 5. Density values and (a) compressive strength, (b) flexural strength of geopolymer pastes after 28 days of hardening, in function of different \% $\mathrm{Al}$ powder additions at S/L: $3.5 \mathrm{~g} / \mathrm{mL}, 8 \mathrm{M} \mathrm{KOH}$ and $70{ }^{\circ} \mathrm{C}$ curing temperature.

It is observed, from Figure 5, that the apparent density decreases substantially as the $\% \mathrm{Al}$ powder increases up to $0.15 \%$, reaching the value of $805 \mathrm{~kg} / \mathrm{m}^{3}$. Further addition of the agent seems to have a negative impact on the board's apparent density, leading to slightly higher values. The density rise in the 0.18 and $0.22 \% \mathrm{Al}$ powder is attributed to the formation of extremely big-sized voids, produced by the high gas amount in the paste, leading to decreased porosity and non-uniform foaming.

The correlation between the mechanical properties and the apparent density of the boards is also presented in Figure 5, showing that both the compressive and flexural strength follow the density's trend, decreasing in the function of Al powder addition $(0.15 \%)$ up to 1.28 and $0.25 \mathrm{MPa}$, respectively, while further agent addition leads to slightly higher values. The typical flexural strength of geopolymer foams is significantly lower than the compressive strength, but it follows a similar trend, as is also reported by Yang et al. [41]; however, flexural strength is more sensitive to the variations in density and pore characteristics compared to compressive strength [42].

The results of Figure 5 are in accordance with the previous publication of Tsaousi et al. [43], where it is reported that the addition of a high volume of foam produces materials with decreased density, and thus, this lowers the mechanical strength. Similar behavior, 
concerning the mechanical properties of the materials in function of the concentration of the foaming agent, is also noted in the case of fly ash geopolymers and geopolymer foam concrete, as indicated by the studies of Nambiar and Ramamurthy [44], Soutsos et al. [45], and Zhang et al. [46], respectively.

The material produced by $0.15 \% \mathrm{Al}$ powder (named GeoFoam), which was selected as more suitable for further evaluation, including water absorption and thermal conductivity evaluation (Table 5), combined low density with satisfying mechanical properties. In addition, the porosity of this material proved acceptable, as the higher addition of foaming agent resulted in extreme expansion conditions with huge pore size formation.

Table 5. Evaluation of optimum produced material.

\begin{tabular}{cccccc}
\hline Material & $\begin{array}{c}\text { Density, } \\
\mathbf{k g} / \mathbf{m}^{\mathbf{3}}\end{array}$ & $\begin{array}{c}\text { Compressive } \\
\text { Strength, } \mathbf{M P a}\end{array}$ & $\begin{array}{c}\text { Flexural } \\
\text { Strength, MPa }\end{array}$ & $\begin{array}{c}\text { Water } \\
\text { Absorption, \% }\end{array}$ & $\begin{array}{c}\text { Th. Conductivity } \\
\text { W/mK }\end{array}$ \\
\hline GeoFoam & 805 & 1.28 & 0.25 & 42.3 & 0.085 \\
\hline
\end{tabular}

The purpose of the thermal conductivity measurement is to investigate if the produced material could be considered as an insulating one, enhancing its total performance of its final application. In comparison with similar commercial materials, the copper slag geopolymers present better thermal conductivity $(0.085 \mathrm{~W} / \mathrm{mK})$ than AAC blocks and foam concrete, with values of 0.12 and $0.1 \mathrm{~W} / \mathrm{mK}$, respectively [18,19]. In this regard, the produced materials could be used as porous masonry materials with great applications in the construction sector, combining very good thermal and physical properties with satisfying mechanical properties.

The water absorption test of the specimens was performed to know the total water absorption capacity of geopolymer foams. As a general trend, the water absorption of the sample reaches high values, which is reasonable, as it belongs in the category of porous materials with a high potential of moisture permeability through its sponge-like structure. Thus, the value of $42.3 \%$ that came out is comparable to similar materials reported in the literature $[47,48]$ and denotes the interconnected cell structure of the material that resulted in channel formation, as can also be confirmed by the following microstructure study of geopolymer foams.

\subsection{Microstructure and Porosity of Geopolymer Foams}

\subsubsection{SEM}

Physical and mechanical properties of GeoFoam are also confirmed by the microstructure study of the material (Figure 6).

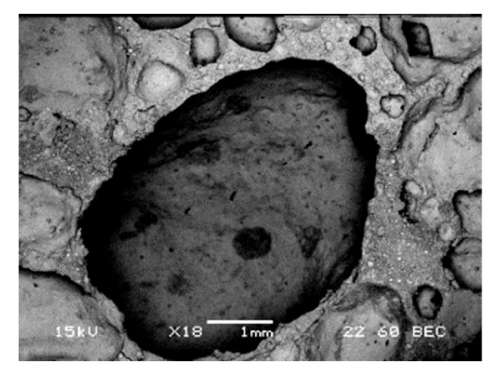

Figure 6. Scanning electron microscopy images of GeoFoam at magnification $\times 18$ and scale $1 \mathrm{~mm}$ (S/L: $3.5 \mathrm{~g} / \mathrm{mL},[\mathrm{KOH}]: 8 \mathrm{M}, \mathrm{Al}$ powder addition: $15 \mathrm{wt} . \%$, curing: $48 \mathrm{~h}$ at $70{ }^{\circ} \mathrm{C}$ ).

GeoFoam presents big pore sizes that are divided by thick walls, justifying the relatively low density of this type of material (compared to compact materials), followed by its limited mechanical properties. The correlation between the apparent density, mechanical performance and porosity is also confirmed by the study by Tsaousi et al. [49], which focused on the development of geopolymer foams using different origin's perlite wastes 
and $\mathrm{H}_{2} \mathrm{O}_{2}$ as a foaming agent. At the same time, Masi et al. [15] and Ducman et al. [20] confirm the above observations, using fly ash as the raw material and hydrogen peroxide, aluminum powder and surfactants as foaming agents.

\subsubsection{Image J Analysis}

Image analysis was applied in the selected sample (GeoFoam) in order to have a semiquantitative evaluation of the porosity (Figure 7).

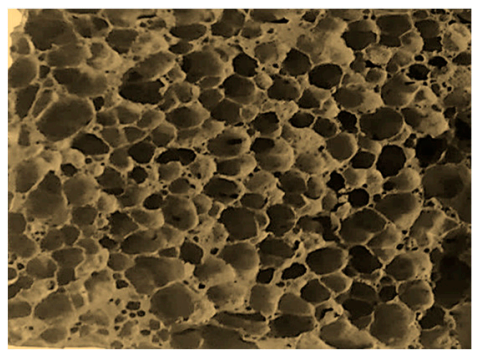

(a) Original scanned image

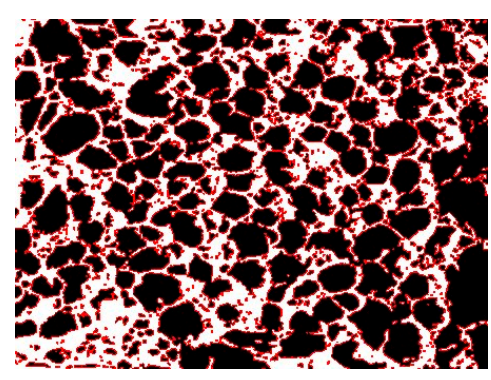

(b) Representation of the original image

Figure 7. Digital processing of the scanned geopolymer foam plates. (a) Original scanned image of the saw-cut flat surface of a sample; (b) with black representing the voids, white the flat material matrix and red the extracted void boundaries.

The pores are shown in a black color surrounded by red boundaries, as opted by the scanned images. The pore size distribution of GeoFoam was estimated through ImageJ analysis (Figure 8). The image processing correlates the surface of the pores and 2D porosity of the samples and converts this correlation to a percentage of the total surface of the image.

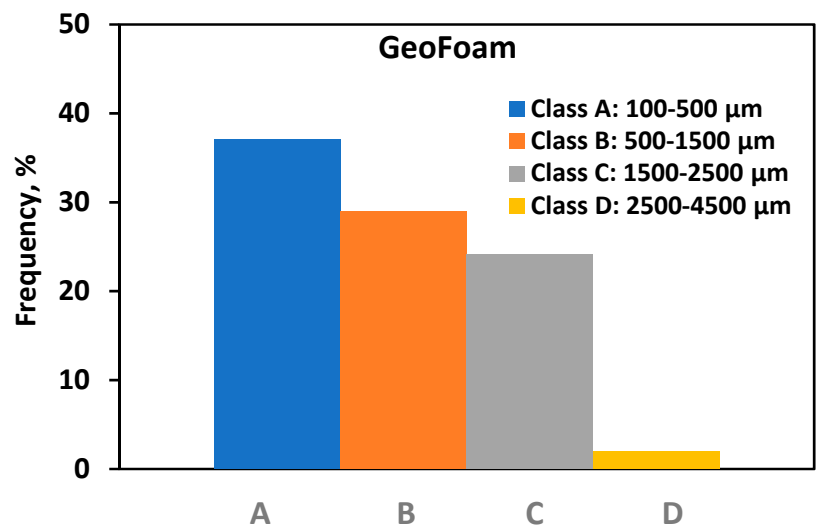

Figure 8. Image J analysis results for frequency $\%$ of voids $/ \mathrm{cm}^{2}$ (vertical axis) against the distribution of the void sizes (area- $\mathrm{cm}^{2}$ ) (horizontal axis) in GeoFoam sample.

According to the results, a porosity of nearly $82.3 \%$ was achieved for the GeoFoam sample, creating an interconnected network of pores, which is in accordance with the microstructure study (Figure 6), minimizing the wall thickness between them and justifying the low compressive strength value.

The pore size distribution (frequency \%) was also evaluated through the image analysis of the samples (Figure 8). Void segmentation measurements of the full polished area of each board have been made, and the results were summarized in a histogram. The horizontal axis contains classes of void sizes for each produced sample. These classes are normalized according to the total area of each sample. The vertical axis represents the frequency of each class in values of the measured total area in $\mathrm{cm}^{2}$ of the detected voids. The data were divided into four classes, while the pore size distribution ranged from 100 to $4500 \mu \mathrm{m}$, 
which is in accordance with the SEM results, including the estimated pore size diameter (220-4220 $\mu \mathrm{m})$.

Even though GeoFoam consists of big pores, as indicated by the microstructure study and digital processing techniques (Figure 6; Figure 7, respectively), the presence of small-sized cells (class A) is intensive, while medium pore sizes (class B and C) are also detected with high frequency. However, a smaller number of bubbles with larger volumes is produced. This appears to be a result of the merging of many smaller bubbles into less larger ones, which was easily demonstrated by the SEM (Figure 6) and scanned images (Figure 7) of the final board. These larger perforated voids clearly form from more circular voids, as can also be detected by the red threshold voids consisting of smaller circular shapes.

Pore size is mainly determined by the material's ability to resist the destabilization mechanisms, such as coalescence and ripening, which are severe at less viscous slurries, failing to keep the generated gas amount inside the matrix. As a result, the films between the bubbles become weak and they start to coalesce, thus increasing the overall pore size and interconnectivity [46,50-52]. This is in accordance with the histogram above, while geo presented not only small-, but also big-sized pores, which can be attributed to the rheological properties of geo (Figure 4), with limited capability to capture the whole amount of gas in the fresh paste. This leads to the abovementioned interconnection of the voids, creating channels with a bigger diameter that have been quantified in the histogram (Figure 8). A similar behavior of geopolymer foams has been reported in a previous study of Tsaousi et al. [49], using perlite as the raw material and $\mathrm{H}_{2} \mathrm{O}_{2}$ as the foaming agent, indicating that the porosity of the material is strongly dependent on the amount of agent in the system. Therefore, the rheological properties of the paste as well as proper agent addition in the system are considered crucial factors, resulting in materials with controlled, homogenous porosity, after the appropriate adjustments. Figure 8 is also in accordance with the published study of Kapat et al. [53], presenting the frequency $\%$ of different pore sizes, in protein foams, based on Ti6Al4V powder dispersion.

\section{Conclusions}

A variety of lightweight materials were produced using $\mathrm{Al}$ powder from 0.12 to $0.22 \%$ in the geopolymer paste. According to the agent's addition, the densities of the materials ranged between 805 and $1100 \mathrm{~kg} / \mathrm{m}^{3}$, corresponding to compressive strength values between 1.28 and $1.82 \mathrm{MPa}$, respectively. The optimum material in terms of lower density, homogenous porosity, and satisfying strength was GeoFoam, with $0.15 \% \mathrm{Al}$ powder (d: $805 \mathrm{~kg} / \mathrm{m}^{3}$ and compressive strength: $1.28 \mathrm{MPa}$ ). GeoFoam was also objected in the thermal conductivity measurement, reaching a value of $0.085 \mathrm{~W} / \mathrm{mK}$. The developed material has a superior thermal conductivity value in relation to the commercial foam concrete [18], which reached $0.2 \mathrm{~W} / \mathrm{mK}$ for a density of $800 \mathrm{~kg} / \mathrm{m}^{3}$, but has inferior compressive strength, which is $15 \%$ lower than the lowest value of the commercial foam concrete. So, optimization of the foaming procedure under pressure in autoclaves must be conducted to improve the mechanical strength of GeoFoam.

So, the produced materials have the potential to be effectively used as thermal insulator panels, masonry units (blocks), and structural members, according to their specifications. These properties vary vastly with the density, and thus a suitable density should be selected based on the intended application [54-58]. Meanwhile, the durability of GeoFoam needs further understanding and improvement towards identifying the lifetime of this material when deployed for each of the abovementioned applications.

Author Contributions: Writing-original draft: G.-M.T.; Writing—review \& editing: D.P. Both authors have read and agreed to the published version of the manuscript.

Funding: This activity has received funding from the European Institute of Innovation and Technology (EIT). This body of the European Union receives support from the European Union's Horizon 2020 research and innovation program. 
Data Availability Statement: Data sharing not applicable. No new data were created or analyzed in this study. Data sharing is not applicable to this article.

Acknowledgments: The research leading to these results has received funding from the EIT Raw Materials Programme IDEAL (2020-2022/No.19040).

Conflicts of Interest: The authors declare no conflict of interest.

\section{References}

1. Eurostat. Statistic Explained. Available online: https:/ / ec.europa.eu/eurostat/statistics-explained/index.php?title=File:Waste_ generation_by_economic_activities_and_households,_EU-28,_2016_(\%25).png\&oldid=413561 (accessed on 29 June 2021$)$.

2. METGrow. Metal recovery from low grade ore and wastes. In EU Horizon 2020 Research and Innovation Program; GA $n^{\circ}$ 690088; European Commission: Brussels, Belgium, 2020. Available online: https:// cordis.europa.eu/project/id/690088 (accessed on 29 June 2021).

3. Panias, D.; Giannopoulou, I.; Perraki, T. Effect of synthesis parameters on the mechanical properties of fly ash-based geopolymers. Colloids Surf. A 2007, 301, 246-254. [CrossRef]

4. Maragos, I.; Giannopoulou, I.; Panias, D. Synthesis of ferronickel slag-based geopolymers. Miner. Eng. 2008, 22, 196-203. [CrossRef]

5. Pontikes, Y.; Machiels, L.; Onisei, S.; Pandelaers, L.; Geysen, D.; Jones, P.T.; Blanpain, B. Slags with a high Al and Fe content as precursors for inorganic polymers. Appl. Clay Sci. 2013, 73, 93-102. [CrossRef]

6. Komnitsas, K.; Zaharaki, D.; Perdikatsis, V. Effect of synthesis parameters on the compressive strength of low-calcium ferronickel slag inorganic polymers. J. Hazard. Mater. 2009, 161, 760-768. [CrossRef]

7. Tsaousi, G.M.; Douni, I.; Panias, D. Experimental Evaluation of Efficient Si Dissolution from Perlite at Low Level Activator's Concentration. Minerals 2018, 8, 160. [CrossRef]

8. Barbosa, V.F.F.; MacKenzie, K.J.D.; Thaumatutgo, C. Synthesis and characterization of materials based on inorganic polymers of alumina and silica: Sodium polysialate polymers. Int. J. Inorg. Mater. 2000, 4, 309-317. [CrossRef]

9. Xu, H.; Van Deventer, J.S.J. The geopolymerization of alumino-silicate minerals. Int. J. Miner. Process. 2000, 3, 247-266. [CrossRef]

10. Palomo, A.; Grutzeck, M.W.; Blanco, M.T. Alkali activated fly ashes-a cement for the future. Cem. Concr. Res. 1999, 8, 1323-1329. [CrossRef]

11. Davidovits, J. Properties of geopolymer cements. In Proceedings of the First International Conference on Alkaline Cements and Concretes, Kiev, Ukraine, 11-14 October 1994; pp. 131-149.

12. Cundi, W.; Hirano, Y.; Terai, T.; Vallepu, R.; Mikuni, A.; Ikeda, K. Preparation of geopolymeric monoliths from red mud-PFBC ash fillers at ambient temperature. In Proceedings of the World Congress Geopolymer, Saint Quentin, France, 28 June-1 July 2005 ; pp. 85-87.

13. Kamseu, E.; Nait-Ali, B.; Bignozzi, M.C.; Leonelli, C.; Rossignol, S.; Smith, D.S. Bulk composition and microstructure dependence of effective thermal conductivity of porous inorganic polymer cements. J. Europ. Ceram. Soc. 2012, 32, 1593-1603. [CrossRef]

14. Zhang, Z.; Provis, J.; Reid, A.; Wang, H. Geopolymer foam concrete: An emerging material for sustainable construction. Constr. Build. Mat. 2014, 56, 113-127. [CrossRef]

15. Williams, B.H. The thermal decomposition of hydrogen peroxide in aqueous solutions. Faraday Soc. 1928, 24, 245-255. [CrossRef]

16. Masi, G.; LesVickers, W.; Bignozzi, M.-C.; Riessen, A. A comparison between different foaming methods for the synthesis of lightweight geopolymers. Ceram. Int. 2014, 40 Pt A, 13891-13902. [CrossRef]

17. Wefers, K.; Misra, C. Oxides and Hydroxides of Aluminum: Technical Report 19-Revised; Alcoa Laboratories: Pittsburgh, PA, USA, 1987; pp. 64-71.

18. Newman, J.; Owens, P. Properties of lightweight concrete. In Advanced Concrete Technology Part 3: Process; Newman, J., Choo, R.S., Eds.; Butterworth-Heinemann Press: Oxford, UK, 2003; Volume 40.

19. Hamad, A.J. Materials, Production, Properties and Application of Aerated Lightweight Concrete: Review. Int. J. Mat. Sci. Eng. 2014, 2, 152-157. [CrossRef]

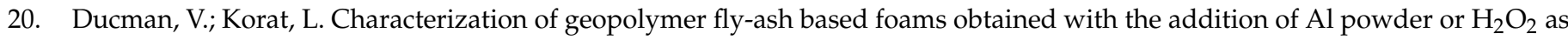
foaming agents. Mat. Charac. 2016, 113, 207-213. [CrossRef]

21. Alengaram, U.J.; Al-Muhit, B.A.; Jumaat, M.Z.; Liu, M.Y.J. A comparison of the thermal conductivity of oil palm shell foamed concrete with conventional materials. Mat. Des. 2013, 51, 522-529. [CrossRef]

22. Song, Y.; Li, B.; Yang, E.H.; Liu, Y.; Ding, T. Feasibility study on utilization of municipal solid waste incineration bottom ash as aerating agent for the production of autoclaved aerated concrete. Cem. Concr. Comp. 2015, 56, 51-58. [CrossRef]

23. Torres, M.L.; García-Ruiz, P.A. Lightweight pozzolanic materials used in mortars: Evaluation of their influence on density, mechanical strength and water absorption. Cem. Concr. Comp. 2009, 31, 114-119. [CrossRef]

24. Liu, M.Y.J.; Alengaram, U.J.; Santhanam, M.; Jumaat, M.Z.; Mo, K.H. Microstructural investigations of palm oil fuel ash and fly ash based binders in lightweight aggregate foamed geopolymer concrete. Constr. Build. Mat. 2016, 120, 112-122. [CrossRef]

25. Komnitsas, K.; Zaharaki, D. Geopolymerisation: A review and prospects for the minerals industry. Miner. Eng. 2007, 20, 1261-1277. [CrossRef] 
26. Singh, P.S.; Bastow, T.; Trigg, M. Structural studies of geopolymers by 29Si and 27Al MAS-NMR. J. Mater. Sci. $2005,40,3951$. [CrossRef]

27. Shi, C.; Hu, S. Cementitious properties of ladle slag fines under autoclave curing condition. Cem. Concr. Res. 2003, 33, 1851-1856. [CrossRef]

28. Setién, J.; Hernández, D.; González, J.J. Characterization of ladle furnace basic slag for use as a construction material. Constr. Build. Mater. 2009, 23, 1788-1794. [CrossRef]

29. Tossavainen, M.; Engstrom, F.; Yang, Q.; Menad, N.; Lidstrom, M.; Larsson, M.; Bjorkman, B. Characteristics of steel slag under different cooling conditions. Waste Manag. 2007, 27, 1335-1344. [CrossRef] [PubMed]

30. Guo, M.; Parada, S.; Jones, P.T.; Boydens, E.; Van Dyck, J.; Blanpain, B.; Wollants, P. Degradation mechanisms of magnesia-carbon refractories by high-alumina stainless steel slags under vacuum. J. Eur. Ceram. Soc. 2009, 29, 1053-1060. [CrossRef]

31. CEN. EN 13755: Natural Stone Test. Methods—Determination of Water Absorption at Atmospheric Pressure; CEN: Nashua, MT, USA, 2008.

32. Kluge, A.L.; Piszora, P.; Darul, J.; Kantel, T.; Gambal, P. Characterization of chemical and physical parameters of post copper slag. Cent. Eur. J. Phys. 2011, 9, 380-386. [CrossRef]

33. Keeley, P.M.; Rowson, N.A.; Johnson, T.P.; Deegan, D.E. The effect of the extent of polymerisation of a slag structure on the strength of alkali-activated slag binders. Int. J. Miner. Process. 2017, 164, 37-44. [CrossRef]

34. Mahendran, K.; Arunachelam, N. Study on utilization of copper slag as fine aggregate in geopolymer concrete. Int. J. Appl. Eng. Res. 2015, 10, 53.

35. Massazza, F. Pozzolana and pozzolanic cements. In Lea's Chemistry of Cement and Concrete; Hewlett, P., Ed.; Arnold: London, UK, 1998; pp. 471-631.

36. Panias, D.; Giannopoulou, I. The geopolymerization technology for the utilization of mining and metallurgical solid wastes. In Proceedings of the European Metallurgical Conference, Dusseldorf, Germany, 11-14 June 2007; pp. 625-640.

37. Davidovits, J. Geopolymer Chemistry and Applications, 2nd ed.; Institut Geopolymere: Saint Quentin, France, 2008; Chapter 26; pp. $547-574$.

38. Heah, C.; Kamarudin, H.; Al Bakri, A.M.; Bnhussain, M.; Luqman, M.; Khairul, N.I.; Ruzaidi, C.; Liew, Y. Study of solid-to-liquid and alkaline activator ratios on kaolin based geopolymers. Const. Build. Mater. 2012, 35, 912-922. [CrossRef]

39. Tsaousi, G.M.; Douni, I.; Panias, D. Characterization of the properties of perlite geopolymer pastes. Mater. Construcc Ión 2016, 66, e102. [CrossRef]

40. Liu, M.Y.J.; Alengaram, U.J.; Jumaat, M.Z.; Mo, K.H. Evaluation of thermal conductivity, mechanical and transport properties of lightweight aggregate foamed geopolymer concrete. Energy Build. 2014, 72, 238-245. [CrossRef]

41. Yang, K.H.; Lo, C.W.; Huang, J.S. Production and properties of foamed reservoir sludge inorganic polymers. Cem. Concr. Compos. 2013, 38, 50-56. [CrossRef]

42. Roviello, G.; Menna, C.; Tarallo, O.; Ricciotti, L.; Messina, F.; Ferone, C.; Asprone, D.; Cioffi, R. Lightweight geopolymer-based hybrid materials. Compos. Part B Eng. 2017, 128, 225-237. [CrossRef]

43. Tsaousi, G.M.; Douni, I.; Taxiarchou, M.; Panias, D.; Paspaliaris, I. Development of foamed inorganic polymeric materials based on Perlite. Mater. Sci. Eng. 2014, 123. [CrossRef]

44. Nambiar, E.K.; Ramamurthy, K. Air-void characterisation of foam concrete. Cem. Concr. 2007, Res37, 221-230. [CrossRef]

45. Soutsos, M.; Boyle, A.P.; Vinai, R.; Hadjierakleous, A.; Barnett, S.J. Factors influencing the compressive strength of fly ash based geopolymers. Constr. Build. Mat. 2016, 110, 355-368. [CrossRef]

46. Zhang, Z.; Provis, J.L.; Reid, A.; Wang, H. Mechanical, thermal insulation, thermal resistance and acoustic absorption properties of geopolymer foam concrete. Cem. Concr. Comp. 2015, 62, 97-105. [CrossRef]

47. Katarzyna, B.; Le, C.H.; Louda, P.; Michał, S.; Bakalova, T.; Tadeusz, P.; Prałat, K. The fabrication of geopolymer foam composites incorporating coke dust waste. Processes 2020, 8, 1052. [CrossRef]

48. Lamond, J.F.; Pielert, J.H. Significance of Tests and Properties of Concrete and Concrete-Making Materials; ASTM International: West Conshohocken, PA, USA, 2006. [CrossRef]

49. Tsaousi, G.M.; Profitis, E.; Douni, I.; Chatzitheodorides, E.; Panias, D. Development of lightweight insulating building materials from perlite wastes National Technical University of Athens. Mater. Constr. 2019, 69, e175. [CrossRef]

50. Huang, Y.; Gong, L.; Shi, L.; Cao, W.; Pan, Y.; Cheng, X. Experimental investigation on the influencing factors of preparing porous fly ash-based geopolymer for insulation material. Energy Build. 2008, 168, 9-18. [CrossRef]

51. Xu, F.; Gu, G.; Zhang, W.; Wang, H.; Huang, X.; Zhu, J. Pore structure analysis and properties evaluations of fly ash-based geopolymer foams by chemical foaming method. Ceram. Int. 2018, 44, 19989-19997. [CrossRef]

52. Zhang, Z.; Wang, H. The pore characteristics of geopolymer foam concrete and their impact on the compressive strength and modulus. Front. Mater. 2016, 3, 38. [CrossRef]

53. Kapat, K.; Kumar, P.; Dhara, S. Coagulant assisted foaming-A method for cellular Ti6Al4V: Influence of microstructure on mechanical properties. Mater. Sci. Eng. A 2017, 689, 63-71. [CrossRef]

54. Zulkarnain, F.; Ramli, M. Performance of foamed concrete mix design with silica fume for general housing construction. Eur. J. Technol. Adv. Eng. Res. 2011, 1, 18-28.

55. Singh, N. Fly ash-based geopolymer binder: A future construction material. Minerals 2018, 8, 299. [CrossRef] 
56. Cavallaro, G.; Lazzara, G.; Lisuzzo, L.; Milioto, S.; Parisi, F. Filling of mater-Bi with Nanoclays to enhance the biofilm rigidity. J. Funct. Biomater. 2018, 9, 60. [CrossRef]

57. Hanzlíček, T.; Perná, I.; Uličná, K.; Římal, V.; Štěpánková, H. The evaluation of clay suitability for geopolymer technology. Minerals 2020, 10, 852. [CrossRef]

58. Lisuzzo, L.; Cavallaro, G.; Milioto, S.; Lazzara, G. Effects of halloysite content on the thermo-mechanical performances of composite bioplastics. Appl. Clay Sci. 2020, 185, 105416. [CrossRef] 